\title{
The effects of n-6:n-3 polyunsaturated fatty acid ratios on serum protein and immunoglobulins in the Yangzhou goose ${ }^{*}$
}

\author{
M.Z. Wang ${ }^{1}$, L.Y. Ding, J.F. Wang, L.H. Yu and H.R. Wang \\ College of Animal Science and Technology, Yangzhou University \\ Yangzhou, Jiangsu province, 225009, P.R. China
}

(Received 1 April 2011; revised version 11 June 2012; accepted 19 June 2012)

\begin{abstract}
This study was conducted to investigate the effects of $n-6: n-3$ polyunsaturated fatty acid (PUFA) ratios on serum protein and immunoglobulins in growing geese. One hundred and sixty healthy Yangzhou geese were randomly divided into 4 groups: diets were designed as 12:1, 9:1, 6:1, and $3: 1$, respectively, by varying dietary n-6:n-3 PUFA ratios. Protein and immunoglobulin levels were measured on $\mathrm{d} 42, \mathrm{~d} 56$, and $\mathrm{d} 70$. The experimental results showed that total protein was highest in group 6:1 on $\mathrm{d} 42(\mathrm{P}<0.05)$, albumin, in group 12:1 on $\mathrm{d} 56(\mathrm{P}<0.05)$, and globulin, in group 6:1 on $\mathrm{d} 42(\mathrm{P}<0.05)$. No significant difference was detected in the albumin/globulin ratio $(\mathrm{A} / \mathrm{G}$ ratio $)$ among groups $(\mathrm{P}>0.05)$; however, the numerical value of the $\mathrm{A} / \mathrm{G}$ ratio of group 3:1 was higher than in any of the other groups at all sampling ages. On d 56 and 70, IgA and IgM were highest in group $3: 1$, whereas $\operatorname{IgG}$ was highest in group 6:1, and these values were significantly higher than in the other groups $(\mathrm{P}<0.05)$. Overall, diets containing low n-6:n-3 PUFA ratios could increase the serum $\mathrm{A} / \mathrm{G}$ ratio, $\operatorname{IgA}, \operatorname{IgG}$, and $\operatorname{IgM}$, in the Yangzhou goose on days 56 and 70 .
\end{abstract}

KEY WORDS: Yangzhou goose, n-6:n-3 PUFA ratios, serum protein, immunoglobulin

\section{INTRODUCTION}

Serum albumin (Alb) is involved in maintaining normal plasma colloid osmotic pressure, transferring small molecular weight materials, and protecting

\footnotetext{
*Supported by the NSFC of China, Grant No. 31072051, and the Natural Science Foundation of Jiangsu province, Grant No. SBK201121885, P.R. China

${ }^{1}$ Corresponding author: e-mail: mengzhiwang@yahoo.cn or mzwang@yzu.edu.cn
} 
globulin (Glb). Serum immune Glb can bind antigens and has antibacterial and antiviral immune properties. Generally, the levels of Alb or Glb in serum are used as indicators of immunological status and bodily health. Polyunsaturated fatty acids (PUFA), including the class of n-6 PUFA and n-3 PUFA, might have profound roles in immunologic regulation (Yaqoob et al., 1994; Wang, 2000; Yaqoob, 2003), such as improving antihypersensitivity, or anti-inflammatory effects. An animal can not convert n-6 PUFA to n-3 PUFA or vice versa; and these two classes are opposed to each other in metabolic function. The appropriate ratio of n-6:n-3 PUFA in a diet is essential for an organism's immune balance and, in contrast, an imbalance of these 2 classes in a specific oil might act as an immune inhibitor (Grimm et al., 1994). Therefore, maintaining a balance of PUFA may be of importance for immunocompetence (Kinsella et al., 1990). Several studies published earlier also showed that the dietary n-6:n-3 PUFA ratio had some impact on antibody titers (Xia et al., 2004), hypersensitivity reactions (Korver and Klasing, 1997), and inflammatory responses (Sijben and Calder, 2007). The suitable range of n-6:n-3 PUFA ratios in the diet to ensure animal health is still not clear.

The Yangzhou goose is a major breed in China and was approved as the first national goose breed by the National Examination and Approval Committee of Domestics Animal and Poultry Breed in 2006. Research on the Yangzhou goose has mainly been on growth performance, carcass characteristics, and meat quality (Lai, 2007; Shi et al., 2007; Wei et al., 2009). No information has yet been available concerning the putative effects of n-6:n-3 PUFA ratios on the immune response in this breed. The hypothesis of the present study was that dietary n-6:n-3 PUFA ratios were associated with levels of serum protein and immunoglobulins in this goose. Diets were, therefore, designed with different PUFA composition, aimed to assay the effect of n-6/n-3 PUFA ratios on serum protein and immune Glb of the Yangzhou goose, and also to afford some reference for the recommendations on the inclusion of oils in feed.

\section{MATERIAL AND METHODS}

\section{Experimental birds and feeding}

The experiment was conducted from November 2009 to March 2010 at the experimental farm of Yangzhou University, Yangzhou (China). All animal handling protocols were approved by the Yangzhou University Animal Care and Use Committee. One hundred and sixty healthy Yangzhou geese ( 80 males and 80 females), of similar weight $(0.407 \pm 0.023 \mathrm{~kg})$, aged 3 weeks, were randomly 
divided into 4 groups. Each group contained 4 replications, with each replication consisting of 10 birds in a block (5 males and 5 females). Birds of each group were randomly allocated to the four diets shown in Table 1, which contained n-6:n-3 PUFA ratios of 12:1, 9:1, 6:1 and 3:1, respectively. The experimental diets were designed by referring to NRC (1994) and some recent studies on the Yangzhou goose (Shi et al., 2007; Wang et al., 2008; Zhou et al., 2008). Palmitic acid (99.9\% purity), and oleic acid (99.9\% purity) were purchased from Zibo Wanyou Chemical Co. Shandong Province (China). The fatty acids were analysed chromatographically (using a SHIMADZU GC-14B gas chromatograph, Shimadzu Corp. Kyoto, Japan) with methyl esterification by $10 \%$ sulphuric acid in methanol $\left(\mathrm{H}_{2} \mathrm{SO}_{4}-\mathrm{CH}_{3} \mathrm{OH}\right)$, and the $\mathrm{N}$ content of feed was determined by the Kjeldahl method (AOAC, 1990); no. 948.13). No vaccinations were given throughout the experimental period, and 3 birds in total died (mortality rate: 1.86\%).

Table 1. Composition and nutritive value of experimental diet (\% unless otherwise stated)

\begin{tabular}{|c|c|c|c|c|}
\hline \multirow{2}{*}{ Diets } & \multicolumn{4}{|c|}{ n-6:n-3 PUFA ratios } \\
\hline & $\mathrm{A}(12: 1)$ & $\mathrm{B}(9: 1)$ & $\mathrm{C}(6: 1)$ & $\mathrm{D}(3: 1)$ \\
\hline \multicolumn{5}{|l|}{ Ingredients } \\
\hline maize & 66.20 & 66.20 & 66.20 & 66.20 \\
\hline soyabean meal & 17.30 & 17.30 & 17.30 & 17.30 \\
\hline lucerne powder & 10.70 & 10.70 & 10.70 & 10.70 \\
\hline peanut oil & 1.30 & 1.28 & 1.16 & 1.06 \\
\hline sunflower seed oil & 0.16 & 0.15 & 0.16 & 0.08 \\
\hline linseed oil & 0.10 & 0.13 & 0.19 & 0.32 \\
\hline palmitic acid & 0.37 & 0.37 & 0.38 & 0.40 \\
\hline oleic acid & 0.07 & 0.07 & 0.11 & 0.14 \\
\hline calcium hydrogen phosphate & 1.20 & 1.20 & 1.20 & 1.20 \\
\hline stone powder ${ }^{2}$ & 0.60 & 0.60 & 0.60 & 0.60 \\
\hline L-lysine hydrochloride & 0.35 & 0.35 & 0.35 & 0.35 \\
\hline methionine & 0.15 & 0.15 & 0.15 & 0.15 \\
\hline sodium chloride & 0.50 & 0.50 & 0.50 & 0.50 \\
\hline premix $^{3}$ & 1.00 & 1.00 & 1.00 & 1.00 \\
\hline \multicolumn{5}{|l|}{ Nutritive value } \\
\hline metabolizable energy, $\mathrm{ME}, \mathrm{MJ} / \mathrm{kg})^{4}$ & 11.70 & 11.70 & 11.70 & 11.70 \\
\hline crude protein & 14.04 & 14.41 & 14.35 & 14.22 \\
\hline n-6 PUFA ${ }^{5}$ & 0.60 & 0.60 & 0.56 & 0.50 \\
\hline n-3 PUFA 5 & 0.05 & 0.07 & 0.09 & 0.16 \\
\hline n-6:n-3 PUFA ratio & $12.00: 1$ & $8.57: 1$ & $6.22: 1$ & $3.12: 1$ \\
\hline \multicolumn{5}{|c|}{ 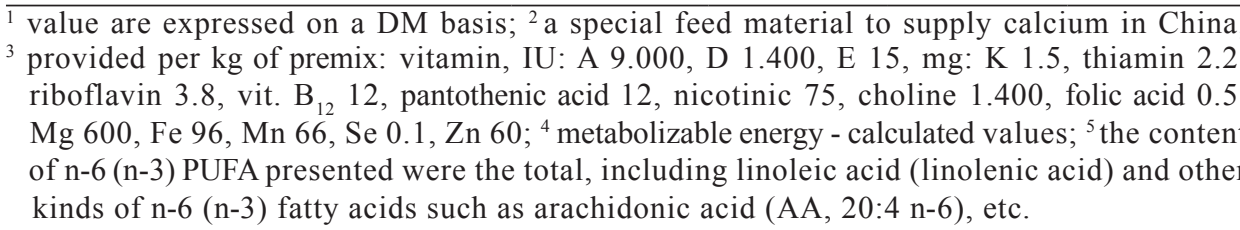 } \\
\hline
\end{tabular}


Gas chromatography of fatty acids

Two millilitres of each treatment oil evaporated under nitrogen gas until dryness at $45^{\circ} \mathrm{C}$ in a rotary evaporator. Then $2 \mathrm{ml}$ of $10 \%$ sulphuric acid in methanol $\left(\mathrm{H}_{2} \mathrm{SO}_{4}-\mathrm{CH}_{3} \mathrm{OH}\right)$ were added into each oil sample tube, capped, and placed in a water bath for $20 \mathrm{~min}$ at $70^{\circ} \mathrm{C}$. Subsequently, $1 \mathrm{ml}$ deionized water and $2 \mathrm{ml}$ hexane were added to each tube. Tubes were recapped and vortexed for $1 \mathrm{~min}$ and then set on a lab bench until the layers separated. The upper organic phase was collected for gas chromatography (GC) analysis.

Analyses were performed with a fused silica capillary column (DB-FFAP), $30 \mathrm{~m} \times 0.25 \mathrm{~mm}$ inner diameter (ID) $\times 0.25 \mu \mathrm{m}$ film thickness (J\&W Scientific, Agilent Technologies), a split/splitless injector, an automatic sampler (model AOC17), and a flame ionization detector in a SHIMADZU GC-14B gas chromatograph (Shimadzu Corp., Kyoto, Japan). The initial temperature programme was: $130^{\circ} \mathrm{C}$ with a $1 \mathrm{~min}$ hold; ramp: $4^{\circ} \mathrm{C} / \mathrm{min}$ to $178^{\circ} \mathrm{C}, 1^{\circ} \mathrm{C} / \mathrm{min}$ to $225^{\circ} \mathrm{C}$, and then $40^{\circ} \mathrm{C} /$ min to $245^{\circ} \mathrm{C}$, with a 13 min hold. Carrier gas was $\mathrm{H}_{2}$, with a linear velocity of $60 \mathrm{~cm} / \mathrm{s}$; a constant pressure of $102.4 \mathrm{kPa}$ was used. Fatty acid analysis was performed by autoinjection of $1 \mu \mathrm{l}$ of each sample at a split ratio of 7.5:1. The FID temperature was $250^{\circ} \mathrm{C}$, with air and nitrogen make-up gas flow rates of 450 and $10 \mathrm{ml} / \mathrm{min}$.

\section{Blood sampling and index measurement}

Eight birds of each group were selected randomly and bled by venipuncture into EDTA-coated tubes at 42, 56, and 70 days, respectively. The blood samples were prepared for total protein (TP), Alb, Glb, and immunoglobulin (IgA, IgG, IgM) analysis. The reagent kit was purchased from Biosino Bio-Technology and Science Incorporation, Beijing (China), and the serum physiochemical and immunologic indexes were examined using an end-point method by a HITACHI7150 Auto-Biochemical Analyzer, in People's Hospital of Subei, Jiangsu Yangzhou (China). The individual methods of analysis are described below:

- total protein (TP): double-reagent biuret method, the result shows a maximum absorption at $540 \mathrm{~nm}$,

- albumin (Alb): bromocresol purple method, the result shows a maximum absorption at $620 \mathrm{~nm}$,

- globulin (Glb): calculated using the formula here, GLB = TP - ALB,

- $\operatorname{IgA}, \operatorname{IgG}$, and IgM: immunologic transmission turbidimetry method, the result shows a maximum absorption at $340 \mathrm{~nm}$.

\section{Statistical analysis}

The experimental results are described as mean \pm standard error. Statistical 
analysis was carried out by ANOVA with the post hoc multiple comparison test of Tukey in software SPSS (Version 16 for windows). P values less than 0.05 are considered statistically significant.

\section{RESULTS}

\section{Effects of n-6:n-3 PUFA on serum TP, ALB, GLB, and A/G ratio}

The results presented in Table 2 show that serum TP increased when Yangzhou geese aged, and was comparatively higher on day 70 . The comparison of 4 treatments indicates that in $6: 1$ it was higher than in $12: 1$ on day $42(\mathrm{P}<0.05)$; while no significant difference was found in TP between treatments on day 56 or $70(\mathrm{P}>0.05)$. Serum Alb also increased generally with age, and moreover, the

Table 2. The effects of n-6:n-3 polyunsaturated fatty acids (PUFA) ratios on serum total protein, albumin, globulin, and albumin/globulin ratio in the Yangzhou goose

\begin{tabular}{|c|c|c|c|c|c|c|c|c|}
\hline \multirow{2}{*}{ Indices } & \multirow{2}{*}{ Ages, days- } & \multicolumn{4}{|c|}{ n-6:n-3 PUFA ratios } & \multirow{2}{*}{ Mean } & \multirow{2}{*}{ SEM } & \multirow{2}{*}{$\mathrm{P}$} \\
\hline & & $\mathrm{A}(12: 1)$ & B $(9: 1)$ & $\mathrm{C}(6: 1)$ & $\mathrm{D}(3: 1)$ & & & \\
\hline \multirow{3}{*}{$\begin{array}{l}\text { Total } \\
\text { protein, } g / 1\end{array}$} & 42 & $\begin{array}{l}36.271^{b} \\
n=7\end{array}$ & $\begin{array}{l}38.625^{\mathrm{ab}} \\
\mathrm{n}=8\end{array}$ & $\begin{array}{l}39.557^{\mathrm{a}} \\
\mathrm{n}=7\end{array}$ & $\begin{array}{l}38.625^{\mathrm{ab}} \\
\mathrm{n}=8\end{array}$ & $\begin{array}{l}38.293 \\
n=30\end{array}$ & 0.958 & 0.017 \\
\hline & 56 & $\begin{array}{l}43.388^{a} \\
n=8\end{array}$ & $\begin{array}{l}42.443^{a} \\
n=7\end{array}$ & $\begin{array}{l}40.575^{\mathrm{a}} \\
\mathrm{n}=8\end{array}$ & $\begin{array}{l}40.688^{a} \\
n=8\end{array}$ & $\begin{array}{l}41.752 \\
n=31\end{array}$ & 1.114 & 0.048 \\
\hline & 70 & $\begin{array}{l}44.713^{\mathrm{a}} \\
\mathrm{n}=8\end{array}$ & $\begin{array}{l}45.225^{\mathrm{a}} \\
\mathrm{n}=8\end{array}$ & $\begin{array}{l}45.213^{\mathrm{a}} \\
\mathrm{n}=8\end{array}$ & $\begin{array}{l}45.338^{\mathrm{a}} \\
\mathrm{n}=8\end{array}$ & $\begin{array}{l}45.122 \\
n=32\end{array}$ & 2.018 & 0.990 \\
\hline \multirow{3}{*}{ Albumin, g/l } & 42 & $\begin{array}{l}14.100^{\mathrm{a}} \\
\mathrm{n}=7\end{array}$ & $\begin{array}{l}14.675^{\mathrm{a}} \\
\mathrm{n}=8\end{array}$ & $\begin{array}{l}14.900^{\mathrm{a}} \\
\mathrm{n}=7\end{array}$ & $\begin{array}{l}15.113^{\mathrm{a}} \\
\mathrm{n}=8\end{array}$ & $\begin{array}{l}14.710 \\
n=30\end{array}$ & 0.509 & 0.256 \\
\hline & 56 & $\begin{array}{l}17.200^{\mathrm{a}} \\
\mathrm{n}=8\end{array}$ & $\begin{array}{l}16.600^{\mathrm{ab}} \\
\mathrm{n}=7\end{array}$ & $\begin{array}{l}15.900^{b} \\
n=8\end{array}$ & $\begin{array}{l}16.363^{\mathrm{ab}} \\
\mathrm{n}=8\end{array}$ & $\begin{array}{l}16.513 \\
n=31\end{array}$ & 0.433 & 0.042 \\
\hline & 70 & $\begin{array}{l}16.913^{\mathrm{a}} \\
\mathrm{n}=8\end{array}$ & $\begin{array}{l}17.563^{\mathrm{a}} \\
\mathrm{n}=8\end{array}$ & $\begin{array}{l}17.750^{\mathrm{a}} \\
\mathrm{n}=8\end{array}$ & $\begin{array}{l}18.400^{\mathrm{a}} \\
\mathrm{n}=8\end{array}$ & $\begin{array}{l}17.656 \\
n=32\end{array}$ & 0.619 & 0.144 \\
\hline \multirow{3}{*}{ Globulin, g/l } & 42 & $\begin{array}{l}22.171^{b} \\
n=7\end{array}$ & $\begin{array}{l}23.950^{\mathrm{a}} \\
\mathrm{n}=8\end{array}$ & $\begin{array}{l}24.657^{\mathrm{a}} \\
\mathrm{n}=7\end{array}$ & $\begin{array}{l}23.513^{\mathrm{ab}} \\
\mathrm{n}=8\end{array}$ & $\begin{array}{l}23.583 \\
n=30\end{array}$ & 0.631 & 0.006 \\
\hline & 56 & $\begin{array}{l}26.188^{a} \\
n=8\end{array}$ & $\begin{array}{l}25.843^{\mathrm{a}} \\
\mathrm{n}=7\end{array}$ & $\begin{array}{l}24.675^{\mathrm{a}} \\
\mathrm{n}=8\end{array}$ & $\begin{array}{l}24.325^{\mathrm{a}} \\
\mathrm{n}=8\end{array}$ & $\begin{array}{l}25.239 \\
\mathrm{n}=31\end{array}$ & 0.739 & 0.053 \\
\hline & 70 & $\begin{array}{l}27.800^{\mathrm{a}} \\
\mathrm{n}=8\end{array}$ & $\begin{array}{l}27.663^{\mathrm{a}} \\
\mathrm{n}=8\end{array}$ & $\begin{array}{l}27.463^{\mathrm{a}} \\
\mathrm{n}=8\end{array}$ & $\begin{array}{l}26.938^{\mathrm{a}} \\
\mathrm{n}=8\end{array}$ & $\begin{array}{l}27.466 \\
n=32\end{array}$ & 1.620 & 0.954 \\
\hline \multirow{3}{*}{$\begin{array}{l}\text { Albumin/ } \\
\text { globulin ratio }\end{array}$} & 42 & $\begin{array}{l}0.637^{a} \\
n=7\end{array}$ & $\begin{array}{l}0.613^{\mathrm{a}} \\
\mathrm{n}=8\end{array}$ & $\begin{array}{l}0.604^{a} \\
n=7\end{array}$ & $\begin{array}{l}0.644^{\mathrm{a}} \\
\mathrm{n}=8\end{array}$ & $\begin{array}{l}0.625 \\
n=30\end{array}$ & 0.021 & 0.217 \\
\hline & 56 & $\begin{array}{l}0.657^{a} \\
n=8\end{array}$ & $\begin{array}{l}0.642^{\mathrm{a}} \\
\mathrm{n}=7\end{array}$ & $\begin{array}{l}0.645^{\mathrm{a}} \\
\mathrm{n}=8\end{array}$ & $\begin{array}{l}0.674^{a} \\
n=8\end{array}$ & $\begin{array}{l}0.655 \\
n=31\end{array}$ & 0.013 & 0.090 \\
\hline & 70 & $\begin{array}{l}0.617^{a} \\
n=8\end{array}$ & $\begin{array}{l}0.638^{a} \\
n=8\end{array}$ & $\begin{array}{l}0.654^{\mathrm{a}} \\
\mathrm{n}=8\end{array}$ & $\begin{array}{l}0.684^{a} \\
n=8\end{array}$ & $\begin{array}{l}0.648 \\
n=32\end{array}$ & 0.031 & 0.194 \\
\hline
\end{tabular}

values with same superscripts in the same row meant no significant difference $(\mathrm{P}>0.05)$; values with different superscripts in the same row meant significant difference $(\mathrm{P}<0.05)$ 
variations of Alb between groups were different depending on the examined ages. Serum Alb was highest in groups 3:1, 12:1, and 3:1, on day 42, 56, and 70, respectively, and a significant difference was found in Alb between treatments on day $56(\mathrm{P}<0.05)$.

Serum Glb increased with the age of the Yangzhou goose. A significant difference was found in Glb between treatments on day $42(\mathrm{P}<0.05)$, but no significant difference existed in Glb among the treatments on day 56 or 70 in Yangzhou geese.

The albumin/globulin ratio (A/G ratio) in groups 6:1 and 3:1 had a tendency to increase with age. Comparison of the treatments showed that no significant difference existed in the $\mathrm{A} / \mathrm{G}$ ratio among the four groups. However, the numerical value of this ratio in group 3:1 was much higher than in the other three groups at all sampling ages.

\section{Effects of n-6:n-3 PUFA on serum immunoglobulin level}

The results shown in Table 3 demonstrate that serum IgA first increased, then declined with age. The IgA level seemed to be much higher on day 56 . A general tendency existed in IgA among the treatments in which IgA increased as the n-6:n-3 PUFA ratio decreased. Moreover, IgA in group 3:1 and 6:1 was

Table 3. The effects of n-6:n-3 polyunsaturated fatty acids (PUFA) ratios on serum IgA, IgG, and IgM in the Yangzhou goose

\begin{tabular}{|c|c|c|c|c|c|c|c|c|}
\hline \multirow{2}{*}{$\begin{array}{l}\text { Immuno- } \\
\text { globulins }\end{array}$} & \multirow{2}{*}{ Ages } & \multicolumn{4}{|c|}{ n-6:n-3 PUFA ratios } & \multirow{2}{*}{ Mean } & \multirow{2}{*}{ SEM } & \multirow{2}{*}{$\mathrm{P}$} \\
\hline & & A $(12: 1)$ & B $(9: 1)$ & $\mathrm{C}(6: 1)$ & $\mathrm{D}(3: 1)$ & & & \\
\hline \multirow{3}{*}{$\operatorname{Ig} \mathrm{A}, \mathrm{g} / \mathrm{l}$} & 42 & $1.447^{\mathrm{c}}$ & $1.686^{b}$ & $2.664^{\mathrm{a}}$ & $2.529^{\mathrm{a}}$ & 2.083 & 0.080 & 0.000 \\
\hline & 56 & $\begin{array}{l}4.651^{c} \\
n=8\end{array}$ & $\begin{array}{l}5.861^{b} \\
n=7\end{array}$ & $\begin{array}{l}5.166^{c} \\
n=8\end{array}$ & $\begin{array}{l}7.113^{a} \\
n=8\end{array}$ & $\begin{array}{l}5.693 \\
n=31\end{array}$ & 0.219 & 0.000 \\
\hline & 70 & $\begin{array}{l}2.848^{b} \\
n=8\end{array}$ & $\begin{array}{l}2.186^{c} \\
n=8\end{array}$ & $\begin{array}{l}2.743^{b} \\
n=8\end{array}$ & $\begin{array}{l}3.503^{a} \\
n=8\end{array}$ & $\begin{array}{l}2.820 \\
n=32\end{array}$ & 0.096 & 0.000 \\
\hline \multirow{3}{*}{$\mathrm{IgG}, \mathrm{g} / \mathrm{l}$} & 42 & $\begin{array}{l}11.653^{b} \\
n=7\end{array}$ & $\begin{array}{l}15.013^{\mathrm{a}} \\
\mathrm{n}=8\end{array}$ & $\begin{array}{l}11.614^{b} \\
n=7\end{array}$ & $\begin{array}{l}9.348^{c} \\
n=8\end{array}$ & $\begin{array}{c}11.925 \\
n=30\end{array}$ & 0.459 & 0.000 \\
\hline & 56 & $\begin{array}{l}10.850^{\mathrm{ab}} \\
n=8\end{array}$ & $\begin{array}{l}8.500^{b} \\
n=7\end{array}$ & $\begin{array}{l}12.350^{\mathrm{a}} \\
\mathrm{n}=8\end{array}$ & $\begin{array}{l}9.663^{b} \\
n=8\end{array}$ & $\begin{array}{c}10.400 \\
n=31\end{array}$ & 0.896 & 0.001 \\
\hline & 70 & $\begin{array}{l}10.903^{c} \\
n=8\end{array}$ & $\begin{array}{l}11.350^{\circ} \\
\mathrm{n}=8\end{array}$ & $\begin{array}{l}18.788^{a} \\
n=8\end{array}$ & $\begin{array}{l}16.288^{b} \\
n=8\end{array}$ & $\begin{array}{c}14.332 \\
\mathrm{n}=32\end{array}$ & 0.484 & 0.000 \\
\hline \multirow{3}{*}{ IgM, g/1 } & 42 & $\begin{array}{l}2.399^{b} \\
n=7\end{array}$ & $\begin{array}{l}2.059^{b} \\
n=8\end{array}$ & $\begin{array}{l}6.344^{a} \\
n=7\end{array}$ & $\begin{array}{l}2.060^{\mathrm{b}} \\
\mathrm{n}=8\end{array}$ & $\begin{array}{l}3.138 \\
n=30\end{array}$ & 0.136 & 0.000 \\
\hline & 56 & $\begin{array}{l}4.305^{c} \\
n=8\end{array}$ & $\begin{array}{l}10.171^{a} \\
n=7\end{array}$ & $\begin{array}{l}7.288^{b} \\
n=8\end{array}$ & $\begin{array}{l}9.429^{a b} \\
n=8\end{array}$ & $\begin{array}{l}7.722 \\
n=31\end{array}$ & 0.814 & 0.000 \\
\hline & 70 & $\begin{array}{l}5.519^{b} \\
n=8\end{array}$ & $\begin{array}{l}4.165^{c} \\
n=8\end{array}$ & $\begin{array}{l}5.210^{\mathrm{b}} \\
\mathrm{n}=8\end{array}$ & $\begin{array}{l}7.284^{a} \\
n=8\end{array}$ & $\begin{array}{l}5.544 \\
\mathrm{n}=32\end{array}$ & 0.166 & 0.000 \\
\hline
\end{tabular}

values with same superscripts in the same row meant no significant difference $(\mathrm{P}>0.05)$; values with different superscripts in the same row meant significant difference $(\mathrm{P}<0.05)$ 
significantly higher than in the other 2 groups on day $42(\mathrm{P}<0.05)$; IgA was highest in group $3: 1$ on $\mathrm{d} 56$ and $70(\mathrm{P}<0.05)$. Among the four groups, the serum IgG level was highest in group 9:1 $(\mathrm{P}<0.05)$ on day 42 and in group 6:1 on both day 56 and $70(\mathrm{P}<0.05)$. It was also observed that the serum IgM level first increased then declined with age. Further observation showed that the IgM level in group 6:1 was highest among treatments $(\mathrm{P}<0.05)$ on day 42 . On day 56 , IgM was higher in groups 3:1 and 9:1 $(\mathrm{P}<0.05)$, and on day 70, IgM was highest in group 3:1 $(\mathrm{P}<0.05)$.

\section{DISCUSSION}

Effects of n-6:n-3PUFA on serum protein. An organism can normally balance the serum protein to maintain normal physiological function. Serum Glb can increase in response to infection by viral or bacterial pathogens. Generally, the $\mathrm{A} / \mathrm{G}$ ratio in blood is more or less steady, and fluctuations of this ratio might indicate that changes of immune status have occurred (Sun et al., 2004; Zhang et al., 2009).

In the present study, the $\mathrm{A} / \mathrm{G}$ ratio in serum showed no significant differences between treatments and it was found that dietary n-6:n-3 PUFA ratios did not have a considerable impact on the $\mathrm{A} / \mathrm{G}$ ratio. Nonetheless, higher $\mathrm{TP}$ or $\mathrm{Alb}$ levels related to diets containing lower n-6:n-3 PUFA ratios (3:1 or 6:1) were found in the current work, and these results agree with those on serum Alb in Arbor Acre broilers reported by Ying (2008). Interestingly, serum Alb and Glb increased, including the $\mathrm{A} / \mathrm{G}$ ratio, as the geese aged. This result indicates that the Alb content in the Yangzhou goose increased faster than the Glb content during the experimental period, especially in group 3:1. This might support the point that a diet with a low n-6:n-3 PUFA ratio exerts a positive impact on immune performance. However, the suitable range of n-6:n-3 PUFA ratio for specific breeds of birds is not yet clear and needs further research.

Effects of n-6:n-3PUFA on immunoglobulins. In comparison with highly saturated fats such as pork fat, fish oil increased the antibody titer of antisheep red blood cells (SRBC) in broilers (Fritsche et al., 1991) and increased the serum antibody titer in broilers (Gao and Lei, 1999) and in laying hens (Chen et al., 2003). This might have been due to the supplementation of the diets with n-3 PUFAs and resulting modulation of membrane architecture and its consequent effects on cells, including immune cells, resulting in improved immune capability. An n-6 PUFA, arachidonic acid, is the precursor of prostaglandins, leukotrienes, and related compounds that have important roles in inflammation and in the regulation of immunity. The competitive relationship existing between these two 
classes is well known, therefore, an imbalance in the n-6:n-3 PUFA ratio might be a potential risk factor for immune inhibition (Reilly and Fitzgerald, 1993; AlMurrani et al., 1997; Calder, 2005). The report by Xia et al. (2004) revealed that the IgG level in egg and serum from laying hens decreased as the n-6:n-3 PUFA ratio increased. A similar work on Arbor Acre broilers described by Ying (2008) showed that serum IgG and Newcastle disease (ND) decreased with an increasing n-6:n-3 PUFA ratio. These results are supported by the results on serum immunoglobulins reported in this study. The IgA, IgG, and IgM contents were higher in the diet containing the $6: 1$ ratio of n-6:n-3 PUFA on day 42 , but higher in the groups fed the diet containing the $3: 1$ ratio of n-6:n-3 PUFA on days 56 and 70. Those results show that a low $n-6: n-3$ PUFA ratio in the diet could improve the level of antibodies in the peripheral blood, which might be beneficial to animal health. The dietary n-6:n-3 PUFA ratio might not reflect the true ratio in tissue or serum due to the complex metabolic processes in the body. Future research on the n-6:n-3 PUFA ratio in relevant tissues and serum, and the influence of the mechanism of the n-6:n-3 PUFA ratio on animal immunity will be necessary.

\section{CONLUSIONS}

Based on the results described above, it can be concluded that a diet containing a low n-6:n-3 PUFA ratio could increase the serum albumin/globulin ratio and level of immunoglobulins (including $\operatorname{IgA}$, IgG, and $\operatorname{IgM}$ ) on day 56 and 70 in the Yangzhou goose.

\section{REFERENCES}

Al-Murrani W.K., Kassab A., Al-Sam H.Z., Al-Athari A.M., 1997. Heterophil/lymphocyte ratio as a selection criterion for heat stress in domestic fowl. Brit. Poultry Sci. 38, 159-163

AOAC, 1990. Association of Official Analytical Chemists, Official Methods of Analysis. 15 $5^{\text {th }}$ Edition. Washington, DC

Calder P.C., 2005. Polyunsaturated fatty acids and inflammation. Biochem. Soc. Trans. Pt 2, 33, 423-427

Chen S.Y., Guo Y.M., Xia Z.G., Yuan J.M., 2003. Effects of different types of poly unsaturated fatty acids on humoral immune fun ction and hepatic lipid peroxidation of laying hens (in Chinese). Acta Nutr. Sinica 25, 383-388

Fritsche K.L., Cassoity N.A., Huang S., 1991. Effect of dietary fat source on antibody production and lymphocyte proliferation in chickens. Poultry Sci. 70, 11-617

Gao S.Z., Lei. F., 1999. Effects of fat sources on immune function in boiling chicken (in Chinese). Chinese Poultry Sci. 23, 4-5

Grimm H., Tibell A., Norrlind B., Blecher C., Wilker S., Schwemmle K., 1994. Immunoregulation by parenteral lipids: Impact of the n-3 to n-6 fatty acid ratio. J. Parent. Enter. Nutr. 18, 417-421 
Kinsella J.E., Lokesh B., Broughton S., 1990. Dietary polyunsaturated fatty acids and eicosanoids effects on the modulation of inflammatory and immune cells: an overview. Nutrition 6, 24-44 Discussion: $59-62$

Korver D.R., Klasing K.C., 1997. Dietary fish oil alters specific and inflammatory responses in chicks. Nutrition 127, 2039-2046

Lai Y.Y., 2007. Research of Characteristic of Fat from Yangzhou Goose. Master Diss (in Chinese). Yangzhou University, Yangzhou (China).http://cdmd.cnki.com.cn/Article/CDMD-11117 -2007 149843.htm

NRC, 1994. Nutrient Requirements of Poultry. 9th revised Edition. National Academy Press. Washington, DC

Reilly M., Fitzgerald G.A., 1993. Cellular activation by thromboxane A2 and other eicosanoids. Eur. Heart J. 14, Supp1., K88-K93

Shi S.R., Wang Z.Y., Yang H.M., Zhang Y.Y., 2007. Nitrogen requirement for maintenance in Yangzhou goslings. Brit. Poultry Sci. 48, 205-209

Sijben J.W., Calder P.C., 2007. Differential immunomodulation with long-chain n-3 PUFA in health and chronic disease. Proc. Nutr. Soc. 66, 237-259

Sun Z.R., She J., Wu Y.J., 2004. The effects on serum ALB, GLB, and A/G ratios of acupuncture acute focal cerebral ischemia rats (in Chinese). Chinese J. Traditional Med. Sci. Technol. 11, 261-262

Wang K., 2000. Enrichment of $\omega-3$ polyunsaturated fatty acid in egg yolk and tissues and its effect on lipid metabolism in laying hens (in Chinese). Master Diss. Graduate School, Chinese Academy of Agricultural Sciences, Beijing (China). http://cdmd.cnki.com.cn/Article/ CDMD82101-2000004902.htm

Wang Z.Y., Shi S.R., Zhou Q.Y., Fan L., Shi Y.J., Xu M.J., 2008. The influence of caecectomy on amino acid availability of three feedstuffs for ganders. Brit. Poultry Sci. 49, 181-185

Wei Z.Y., Zhang J.Z., Yu L.H., Wang H. R., Wang M. Z., 2009. Effects of dietary energy levels on performance and fat deposition of Yangzhou goslings from 6 to 10 weeks of age (in Chinese). Acta Nutr. Sinica 21, 659-664

Xia Z.G., Guo Y.M., Chen S.Y., Yuan J.M., 2004. effects of different types of polyunsaturated fatty acids on antibody responses and lymphocyte multiplication in laying hens (in Chinese). Acta Nutr. Sinica 16, 29-35

Yaqoob P., 2003. Fatty acids as gatekeepers of immune cell regulation. Trends Immunol. 24, 639645

Yaqoob P., Newsholme E.A., Calder P.C., 1994. The effect of dietary lipid manipulation on rat lymphocyte subsets and proliferation. Immunology 82, 603-610

Ying Y., 2008. Effect of different dietary ratios of n-6/n-3 PUFA on the immune functions in chicken (in Chinese). Master Diss. Gansu Agricultural University, Lanzhou (China), pp. 22-27 http:// cdmd.cnki.com.cn/Article/CDMD-10733-2009029074.htm

Zhang Z.Q., Lu W., Cui C.R., Shi J.G., 2009. The practical value of serum albumin and globulin for diagnosing hepatitis B-associated cirrhosis (in Chinese). Prac. J. Med. 25, 374-376

Zhou Y.Q., Wang Z.Y., Shi S.R., Yang H.M., 2008. The Optimal Met requirement of Yangzhou goslings of 5 10 weeks ages. Acta Nutr. Sinica 20, 34-39 